\title{
Environmentally Friendly Behaviors and Environmental Attitudes of 6th Grade Middle-School Students
}

\author{
Selenay Oktan \\ Elementary Science Education Department, \\ Akdeniz University, 07058 Antalya, Turkey \\ E-mail: selenay-1995@windowslive.com \\ Ugur Demet \\ Elementary Science Education Department, \\ Akdeniz University, 07058 Antalya, Turkey \\ E-mail: ugurdemet2013@gmail.com \\ Esme Hacieminoglu (Corresponding author) \\ Elementary Science Education Department, \\ Akdeniz University, 07058 Antalya, Turkey \\ E-mail: ehacieminoglu@gmail.com \\ ORCID: 0000-0001-9318-3931
}

\begin{abstract}
The aim of this study is to determine the 6th grade students' environmentally friendly behaviors and attitudes towards the environment. The sample of this survey designed study consisted of 375 th grade students enrolled in the central schools of Antalya. The "Environmental Attitudes Scale" was used to determine the attitude levels of students towards the environment, and the "Environment Friendly Behavior Questionnaire" was used as a data collection tool to determine environmentally friendly behaviors. Descriptive statistics and independent samples t-test were used as data analyses technique. As a result of the research, it was concluded that while the 6th grade students 'attitudes and behaviors towards the environment were at an acceptable level. When the average scores of the students' attitude towards the environment and their environmentally friendly behaviors were examined in terms of gender, it was concluded that there was no significant difference for male and female students.
\end{abstract}

Keywords: environmentally friendly behaviors, attitudes towards the environment, middle school students

DOI: $10.7176 / J S T R / 7-04-09$

\section{Ortaokul 6. Sınıf Öğrencilerinin Çevre Dostu Davranışları ve Çevreye Yönelik Tutumları}

\section{Özet}

Bu çalışmanın amacı ilköğretim 6. Sınıf öğrencilerinin çevre dostu davranışlarını ve çevreye yönelik tutumlarını belirlemektir. Betimsel tarama modeli kullanılan bu araştırmanın örneklemini Antalya ilinin merkez okullarında öğrenim gören 375 6.sınıf öğrencisi oluşturmuştur. Öğrencilerin çevreye yönelik tutum düzeylerini belirlemek amacıyla "Çevresel Tutumlar Ölçeği”, çevre dostu davranışlarını belirlemek amacıyla da "Çevre Dostu Davranış Anketi”" veri toplama aracı olarak kullanılmıştır. Veriler betimsel analiz ve bağımsız örneklem t-Testi ile analiz edilmiştir. Araştırma sonucunda 6. Sınıf öğrencilerin çevreye yönelik tutum ve davranışları kabul edilebilir düzeyde iken, öğrencilerin çevreye yönelik tutum puanlarının ortalamasının ve çevre dostu davranışlarına ait puanlarının ortalamasının cinsiyet bakımından incelendiğinde erkek ve kız öğrenciler için anlamlı bir farklılığın ortaya çıkmadığı sonucuna ulaşılmıştır.

Anahtar Kelimeler: çevre dostu davranış, çevreye yönelik tutum, ortaokul öğrencileri

87 | $P$ a g e

www.iiste.org 


\section{Giriş}

Çevre sözcüğü, her ne kadar sade görünse de, genel olarak ele alındığında, kompleks bir oluşum olduğu görülür. Çevre hakkında genelleme yapılırsa, bireylerin etkinlikleri ve canlı hayatların üstünde, anlık ya da bir zaman dilimi içerisinde doğrudan ya da görülmeyen bir tesiri olabilecek gerek fiziki, gerek kimyevi gerekse biyolojik etkenleri ve sosyal şartların belli süreçlerdeki bütünüdür (Hamamc1, 1997). Yaşadığımız zamanda gelişmişini tamamlamış ve gelişmeye devam eden olan toplumlarda, hayatsal gereksinimlerle beraber temiz ve yaşanılabilir bir çevrenin de en gerekli ihtiyaç olduğu düşünülmektedir. Birbirinden farklı milli ve milletler arası sivil toplum örgütleri ve birbirinden farklı sivil toplum kuruluşları çevresel kirlenmenin önüne geçmek için çevre merkezli davranışlar ortaya koymaya başlamışlardır (Hamarat, Güler, Duman, Gümüş ve Tufan, 2014). Bir bireyde bulunması gereken asıl çevreci kazanımlar çocukluk dönemlerinde yaparak yaşayarak öğrenilir. Bu nedenle gerçekleştirilen etkileşmenin ve yaşantıların da etkisiyle çocuk ve gençler dâhil olmak üzere tüm bireylerde doğa yaşamı sevgisi ve çevre duyarlılı̆̆ı daha çok erken çağlarda edinildiği zaman kirlenme ve çevreye verilen zararların önüne geçilmesi faaliyetlerin de güçlü bir alt yapı oluşturulması gerçekleştirilecektir (Ayvaz, 1998).

Bizden sonraki bireylerin daha ferah ve güvenli bir çevrede hayatlarına devam etmelerini sağlamak için çevreye karşı bilinçli vatandaşlar oluşturabilmek, zorunlu hal almıştır (Şahin, Cerrah, Saka, Şahin, 2004). Çünkü günümüzde ortaya çıkan durumlardan dolayı çevrede meydana gelen sorunlara çözüm yolları üretmek için bilinçli bireylerin etkisi çok büyük olacaktır. Bundan dolayı okul çağındaki bireylerin çevre eğitimini etkili şekilde almaları oldukça önem arz etmektedir (Erol ve Gezer, 2006).

Çevre sorunları insan hayatına yönelik bir tehdit oluşturmakta ve aynı zamanda dünyamızı gün geçtikçe yaşanamaz hale getirmektedir. Sorunların çözümü ise bireylerin bazı düşünce ve davranışlarının değişmesi ile mümkün olacaktır. Bundan dolayı her bireyin çevre sorunlarına karşı olumlu tutum ve davranış geliştirmede gerekli hassasiyeti göstermelidir. Çevresel sorunların ortadan kaldırılması, davranışlarda oluşturulacak değişiklikler ve çevre bilincinin kazandırılması ile mümkün olabilir. Davranışların değişmesi aynı zamanda bilgi ve tutumların da değişmesini gerekli hale getirir (Erten, 2005). Olumlu tutum ve davranışların değişmesi de bireylere bu bilinci aşılayabilecek amaçları olan çevre eğitimi sayesinde gerçekleşecektir. Çevre eğitimi; toplumu oluşturan bütün bireylerde çevre duyarlılığının daha iyi bir duruma getirilmesi, çevreye karşı hassas ve pozitif davranışların oluşturulması ve natürel, tarih bakımından önemli ve kültürel mirasın değerinin bilinmesi, etkin bir katılım oluşturulması ve karşılaşılan sıkıntıların ortadan kaldırılmasında sorumluluk sahibi olma olarak nitelendirilebilir. Çevre eğitimi, çevre bilimi hakkında bilgileri aktarmanın yanında çocuklarda çevreye karşı tutumlarının daha iyi hale getirilmesi ve tutumların davranış haline gelmesini sağlar (Erten, 2005).

Tutum, bir cansız varlığa, her hangi bir davranışa veya bir vakaya dair geliştirilen, devamlı duygu, düşünce ve davranış birleşiminden meydana gelen bir eğilim durumudur. Kişiler tutumlarını hayatları boyunca, bazen öz tecrübelerine, bazen başkalarının aktardıklarına, bazen de tümünün birlikte yer aldığı etkileşime dayalı olarak kuvvetlendirilirler (Türküm, 1998). Tutumlar bilgi, duygu, düşünce ile bireysel ve toplumsal değerlere bağlı olarak gelişim gösterirler. Ayrıca her bireyde farklılık gösterebilir. Bir insanın tutumu kişinin neyi aklından geçirdiği, neye inanç gösterdiğini ve nelerin farkına vardığının göstergesidir (Sakallı, 2001; akt. Kahyaoğlu, Daban ve Yangın, 2008). Çevre bilgisine sahip olan insanların bilgi birikimini tutum ve davranışına aktarması ve gözle görülür etkiler yaratması beklenir. Başka bir deyişle; çevreye karşı negatif düşünceler barındıran kişilerin çevresel problemlere kayıtsız olma durumu ve bilakis çevreye için sıkıntı yaratacak davranışlarını sürdürme eğilimi kaçınılmazdır (Uzun ve Sağlam, 2006). Çevre konusunda bilgi sahibi olmasına rağmen bunu davranışlarında gösteremeyen bireyler bulunduğu gibi, çevre dostu olup çevrenin zarar görmesinden kuşku duyan, fakat çevreye sahip çıkma gibi davranışlar sergileyemeyenler de toplum içinde yer alabilmektedir. Bireyler çevresinde yer alan diğer canlılarla iletişimi esnasında öğrenme geçmişi yaşayarak farklı tutumlar elde eder, farklı davranışları yapmayı ve yapmamayı öğrenir. Çevreye dair pozitif tutum; kişilerin çevreye sahip çıkılması ve varlıkların yaşamına dair pozitif bakış açısı ve davranışları barındırır. Bu denli bir tutumun gerçekleşmesi için lazım olunması gereken; güzel tecrübelerin yer aldığı bir yaşantı ve bilgi birikimin olmasıdır (Türküm, 1998).

Etkili bir çevre eğitimi ile insanlarda çevre konusundaki duyarlık, sorgulama becerisi, problem çözebilme becerisi ve karar verebilme becerileri de gelişir (Uzunoğlu, 1996). Geçirdiğimiz yirmi yıl içerisinde ana sınıfı ve ilköğretim çağında bulunan çocuklar için çevresel farkındalık faaliyetlerinin öğretim programları içerisinde sıkça yer verilmeye başlanmıştır (Kavak, 1997).

$\mathrm{Bu}$ nedenle bu araştırmanın amacı, "İlköğretim 6.sınıf öğrencilerinin çevre dostu davranışlarını ve

88 | P a g e

www.iiste.org 
çevreye yönelik tutumlarını belirlemektir.” Bu amaç çerçevesinde aşağıdaki sorulara cevap aranmıştır;

1- Ortaokul 6.sınıf öğrencilerinin çevre dostu davranışları ve çevreye yönelik tutumları ne düzeydedir?

2- Ortaokul 6.sınıf öğrencilerinin cinsiyetleri ile çevre dostu davranışları ve çevreye yönelik tutumları arasında anlamlı bir fark var mıdır?

\section{Yöntem}

$\mathrm{Bu}$ çalışma deseni öğrencilerin çevre dostu davranışlarını ve çevreye yönelik tutumlarını ortaya koymayı amaçlayan, betimsel tarama modelidir (survey design). Betimsel tarama modeli, mevcut durumda var olan bir olayı nitel veya nicel yönden betimleyen bir tarama modeli olarak karşımıza çıkmaktadır. Bu modelin en belirgin özelliği ise, var olan bir olayın veya durumun olduğu gibi açıklanmasıdır (Fraenkel and Wallen, 2006)

\section{Çalışmanın örneklemi}

Araştırmanın örneklemini Antalya ilinin merkez okullarında öğrenim gören 375 6.sınıf öğrencisi oluşturmuştur. Araş̧ırmada anketi cevaplayan öğrencilerin \%54,4'i kadın, \%45,3'u erkek öğrencilerden oluşurken; \%0,3'i ise cinsiyet kısmını boş bırakmışlardır.

Tablo 1: Öğrencilerin Cinsiyetine İlişkin Betimsel İstatistik Analiz Sonuçları

\begin{tabular}{lll}
\hline Grup & N & $\%$ \\
Kadın & 170 & 45,3 \\
Erkek & 204 & 54,4 \\
Toplam & 374 & 99,7 \\
\hline
\end{tabular}

Tablo1 'e göre, araştırmaya katılan 170 kadın öğrenci, 204 erkek öğrenci bulunmaktadır. Buna göre, öğrencilerin cinsiyet dağılımlarının benzer olduğu söylenebilir.

\section{Veri Toplama Araçları \\ Çevre Dostu Davranış Anketi}

Araştırmaya katılan öğrencilerin çevre dostu davranışları belirlemek amacıyla Kabaş (2018) in Merting (2003) tarafindan geliştirilmiş ve Higde, Öztekin ve Şahin (2017) tarafindan Türkçeye uyarlanan çevre dostu davranış ölçeği; Kabaş (2018) tarafından Doğa Eğitimi ve Bilim Okulları Projesinde 5.sınıf ilköğretim öğrencileri için düzenlenmiş ve uygulanmıştır. Uygulanan ölçeğin pilot çalışması, 161 5.sınıf öğrencisi ile gerçekleştirilmiştir. Uygulama sonucunda elde edilen verilerin analizi sonucunda ölçeğin Cronbach alpha güvenirlik katsayısı .83 olarak belirtilmiștir. Kabaș (2018) tarafindan Doğa Eğitimi ve Bilim Okulları Projesinde uygulanılan ölçek 15 madden meydana gelmiş 5'li likert tipi bir ölçek kullanılmıştır.

\section{Çevresel Tutumlar Ölçeği}

Araştırmada ilköğretim öğrencilerinin çevreye yönelik tutum düzeylerini belirlemek için Thomson ve Barton (1994) tarafından geliştirilen ölçek, Higde, Öztekin ve Şahin (2017) tarafindan uygulanan 23 maddeden meydana gelmiş 5'li likert tipi ölçektir. Geliştirilen bu ölçek Kabaş (2018) tarafindan Doğa Eğitimi ve Bilim Okulları Projesinde 5.sınıf ilköğretim öğrencileri için düzenlenmiş ve uygulanmıştır. Uygulanan ölçeğin pilot çalışması 1615 .sınıf öğrencisi ile gerçekleştirilmiştir. Çevresel tutumlar ölçeği 2 boyuttan meydana gelmektedir. Bu boyutlar insan merkezli ve çevre merkezli olmak üzere karşımıza çıkmaktadır. 2 boyuttan meydana gelen bu ölçek, Doğa Eğitimi ve Bilim Okulları Projesinde 5.sınıf ilköğretim öğrencileri için düzenlenmesi gerçekleştirilen bu ölçek; yapılan faktör analizleri sonucunda tek boyut olarak uygulanması gerçekleştirilmiştir. Uygulanan pilot çalışma sonucunda elde dilen verilerin analizleri sonucunda Çevre Tutum Ölçeğinin Cronbach alpha güvenirlik katsayısı ,80 olarak belirtilmiştir.

\section{Bulgular}

\section{Birinci Alt Probleme Ait Bulgular}

Araştırmanın birinci alt problemi "Ortaokul 6.sınıf öğrencilerinin çevre dostu davranışları çevreye yönelik tutumları ne düzeydedir?" şeklindedir. Öğrencilerin çevre dostu davranış ölçeğine verdiği cevaplar ile ilgili örnek maddeler Tablo 2 . de verilmiş̧ir.

89 | P a g e

www.iiste.org 
Tablo 2. Öğrencilerin çevre dostu davranışlarına ilişkin verdikleri cevapların yüzdelik (\%) dağılımları

\begin{tabular}{|c|c|c|c|c|c|}
\hline Örnek maddeler & SD & $\mathrm{D}$ & $\mathrm{U}$ & A & SA \\
\hline $\begin{array}{l}\text { 1-Kisa mesafelerde motorlu taşıtlara (araba, motorsiklet, } \\
\text { otobüs vb.) binmek yerine yürümeyi ya da bisiklete binmeyi } \\
\text { tercih ediyorum. }\end{array}$ & 5.6 & 6.9 & 25.6 & 25.1 & 36.8 \\
\hline 2-Çevre koruması ile ilgili etkinliklere katılıyorum. & 7.2 & 16.5 & 24.8 & 23.2 & 26.7 \\
\hline 3-Özellikle doğada geri dönüşebilen ürünleri satın alıyorum. & 9.1 & 12.3 & 25.9 & 30.9 & 20.3 \\
\hline 4-Yere atılmış çöpleri topluyorum. & 4.0 & 9.9 & 24.5 & 26.6 & 31.2 \\
\hline 5-Odadan çıkan en son kişiysem ışıkları kapatıyorum. & 2.7 & 2.7 & 3.2 & 16.5 & 71.7 \\
\hline $\begin{array}{l}\text { 6-Dişlerimi firçalarken ya da banyo yaparken az su } \\
\text { tüketmeye özen gösteriyorum. }\end{array}$ & 3.2 & 5.1 & 8.0 & 20.0 & 60.0 \\
\hline 7-Çevreyle ilgili konuları içeren kitaplar okuyorum. & 7.7 & 18.7 & 28.3 & 23.7 & 21.3 \\
\hline
\end{tabular}

(SD: Kesinlikle Katılmıyorum, D: Katılmıyorum, U: Kararsızım, A:Katılıyorum, SA: Kesinlikle Katıliyorum)

Tablo 2'e göre, öğrencilerin çevre dostu davranışlarına verdikleri cevapların yüzdece dilimleri incelendiğinde; \%71,7 ile "Odadan çıkan son kişiysem 1şıkları kapatırım." sorusuna kesinlikle katılıyorum ile en yüksek katılımı sağlamıştır. Daha sonra \%60'lık katılım ile "Dişlerimi firçalarken ya da banyo yaparken az su tüketmeye özen gösteriyorum.” sorusu kesinlikle katılıyorum cevabını almıştır.

Öğrencilerin en çok kararsız oldukları sorular ise şu şekilde yer almaktadır; \%28.2 kararsızım katılımıyla "Çevre ile ilgili konuları içeren kitaplar okuyorum.", \%25.9 karasızım katılımıyla "Özellikle doğada geri dönüştürülebilen ürünleri satın alıyorum.", \%25.6 kararsızım katılımıyla "Kısa mesafelerde motorlu taşıtlara (araba, motorsiklet, otobüs vb.) binmek yerine yürümeyi ya da bisiklete binmeyi tercih ediyorum.", \%24,8 karasızım katılımıla "Çevre koruması ile ilgili etkinliklere katılıyorum." ve \% 24,5 karasızım katılımıyla "Yere atılıı̧ çöpleri topluyorum." soruları olmuştur.

Öğrencilerin çevreye yönelik tutum ölçeğine verdiği cevaplar ile ilgili örnek maddeler Tablo 3. de verilmiştir.

Tablo 3'e göre, öğrencilerin çevreye karşı tutumlarına verdikleri cevapların yüzdece dilimleri incelendiğinde; \%62,4 kesinlikle katıllyorum cevabı ile "Doğal kaynakları korumak, insanları daha sağlıkl, huzurlu ve temiz çevrede yaşamalarını sağlar.", \%60.3 kesinlikle katılıyorum cevabı ile "Doğanın korunmasının en önemli nedeni; insan, hayvan ve bitki gibi canlıların yaşamının devamını sağlamaktır." ve "Doğal kaynakları yaşamımızı sürdürmek için korumalıyız." soruları olmuştur. Bunun yanı sıra; "Aşırı nüfus artışının en kötü yanı doğal alanların (orman, çevre) yok ediliyor olmasıdır", "Ormanların yok olması hakkında beni en çok endişelendiren şey, gelecek nesiller için yeterli ağaç bulunmayacak olmasıdır", "Çevreye zarar verilmesini görmek beni üzer", "Doğal kaynakları korumanın en önemli nedenlerinden biri, doğal yaşam alanlarının devamlılığını sağlamaktır", "Ağaç dikmek, tohum ekmek ve çiçek dikmek elverişli hale getirilmesi ve düzenlenmesi, insanların sağlıklı ve huzurlu ortamda yaşamaları için iyi bir fikirdir", "İ̉nsanlar da, diğer hayvanlar kadar doğanın bir parçasıdır” seklindeki ifadelerle ilgili olarak öğrencilerin \%50 den fazlası kesinlikle katılıyorum cevabını vermişlerdir.

Öğrencilerin \%24.5 karasızım cevabı ile en yüksek katılımı "Yağmur ormanlarının kaybının en kötü yanı, yeni ilaçların geliştirilmesinin sınırlanacak olmasıdır." İfadesi olmuştur. Diğer bir yüksek kararsızım katılımı \%23,7 ile "Eğer insan hayatını kurtarabilecekse, hayvanlar bilimsel deneylerde kullanılabilir." cevabı olurken \%19.5 kararsızım katılımıyla "Nehirleri ve gölleri temiz tutmanın en önemli nedenlerinden biri insanlara su sporları yapacakları yerler sağlamaktır." ifadesi olmuştur. 
Tablo 3: Öğrencilerin çevreye yönelik tutumlarına ilişkin verdikleri cevapların yüzdelik (\%) dağılımları

\begin{tabular}{|c|c|c|c|c|c|}
\hline Örnek maddeler & SD & $\mathrm{D}$ & $\mathrm{U}$ & $\mathrm{A}$ & SA \\
\hline $\begin{array}{l}\text { 1-Aşırı nüfus artışının en kötü yanı doğal alanların (orman, } \\
\text { çevre) yok ediliyor olmasıdır. }\end{array}$ & 6.7 & 4.0 & 7.2 & 17.6 & 54.1 \\
\hline $\begin{array}{l}\text { 2-Yağmur ormanlarının kaybının en kötü yanı, yeni } \\
\text { ilaçların geliştirilmesinin sınırlanacak olmasıdır. }\end{array}$ & 5.6 & 6.7 & 24.5 & 22.9 & 27.2 \\
\hline $\begin{array}{l}\text { 3-Ormanların yok olması hakkında beni en çok } \\
\text { endişelendiren şey, gelecek nesiller için yeterli ağaç } \\
\text { bulunmayacak olmasıdır. }\end{array}$ & 5.3 & 2.9 & 8.5 & 17.9 & 54.4 \\
\hline $\begin{array}{l}\text { 4-Nehirleri ve gölleri temiz tutmanın en önemli } \\
\text { nedenlerinden biri insanlara su sporları yapacakları yerler } \\
\text { sağlamaktır. }\end{array}$ & 11.2 & 10.9 & 19.5 & 22.1 & 24.8 \\
\hline 5-Çevreye zarar verilmesini görmek beni üzer. & 3.5 & 3.2 & 6.4 & 20.0 & 55.5 \\
\hline $\begin{array}{l}\text { 6-Doğanın korunmasının en önemli nedeni; insan, hayvan } \\
\text { ve bitki gibi canlıların yaşamının devamının sağlanmasıdır. }\end{array}$ & 7.2 & 3.2 & 7.5 & 14.7 & 60.3 \\
\hline $\begin{array}{l}\text { 7-Doğal kaynakları yaşamımızı sürdürmek için } \\
\text { korumalıyız. }\end{array}$ & 5.3 & 2.9 & 6.1 & 17.6 & 60.3 \\
\hline $\begin{array}{l}\text { 8-Doğal kaynakları korumak, insanların daha sağlıkl, } \\
\text { huzurlu ve temiz çevrede yaşamalarını sağlar. }\end{array}$ & 4.3 & 2.1 & 5.3 & 18.4 & 62.4 \\
\hline $\begin{array}{l}\text { 9-Doğal kaynakları korumanın en önemli nedenlerinden } \\
\text { biri, doğal yaşam alanlarının devamlılığını sağlamaktır. }\end{array}$ & 2.4 & 3.7 & 9.6 & 24.3 & 52.5 \\
\hline $\begin{array}{l}\text { 10-Ağaç dikmek, tohum ekmek ve çiçek dikmek elverişli } \\
\text { hale getirilmesi ve düzenlenmesi, insanların sağlıklı ve } \\
\text { huzurlu ortamda yaşamaları için iyi bir fikirdir. }\end{array}$ & 3.7 & 2.7 & 8.8 & 19.5 & 57.6 \\
\hline $\begin{array}{l}\text { 11-İnsanlar da, diğer hayvanlar kadar doğanın bir } \\
\text { parçasıdır. }\end{array}$ & 4.5 & 4.0 & 5.3 & 20.3 & 58.9 \\
\hline $\begin{array}{l}\text { 12-Ĕger insan hayatını kurtarabilecekse, hayvanlar bilimsel } \\
\text { deneylerde kullanılmalıdır. }\end{array}$ & 26.7 & 10.1 & 23.7 & 13.9 & 18.4 \\
\hline $\begin{array}{l}\text { (SD: Kesinlikle Katılmıorum, D: Katılmıyorum, U: Ka } \\
\text { Katıliyorum) }\end{array}$ & 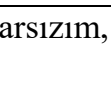 & & & SA: & inli \\
\hline
\end{tabular}

Tablo 4: Öğrenciler için ortalama ve standart sapma değerleri

\begin{tabular}{|c|c|c|c|c|c|}
\hline & $\mathrm{N}$ & Minimum & Maksimum & Ortalama & $\begin{array}{l}\text { Standart } \\
\text { Sapma }\end{array}$ \\
\hline 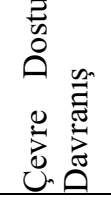 & 375 & 1.33 & 8.57 & 3.84 & .86 \\
\hline 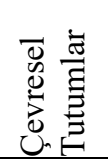 & 354 & 1.43 & 13.70 & 4.03 & .88 \\
\hline
\end{tabular}

Tablo 4' te belirtilen betimsel istatistik sonuçlarına göre, değişkenlerin ortalama skorları incelendiğinde ilköğretim 6.sınıf öğrencilerinin çevre dostu davranış skorları $(\mathrm{M}=3.84$, Ss=.86) ve çevreye karşı tutum skorları $(\mathrm{M}=.88, \mathrm{Ss}=.88)$ olumlu ve kabul edilebilir düzeydedir.

91 | P a g e www.iiste.org 
Íkinci Alt Probleme Ait Bulgular

Ortaokul 6.sınıf öğrencilerinin cinsiyet ile çevre dostu davranışları ve çevreye karşı yönelik tutumları arasında anlamlı bir fark var midır?

Bu bölümde ilköğretim 6.sınıf öğrencilerinin cinsiyet ile çevre dostu davranışları ve çevreye yönelik tutumları arasında anlamlı bir farklılık gösterip göstermediğini incelemek için Bağımsız Örneklem TTesti uygulanmıştır. İlk olarak bağımsız örneklem t-testinin varsayımları kontrol edilmiştir.

İlköğretim 6.sınıf öğrencilerinin çevre dostu davranışları ve çevreye karşı tutumları cinsiyete göre bağımsız örneklem t-testi sonuçları Tablo 5'de gösterilmiştir.

Tablo 5:Öğrencilerin çevre dostu davranışları ve çevreye karşı tutumları cinsiyete göre bağımsız örneklem t-testi sonuçları

\begin{tabular}{llllllll}
\hline & Cinsiyet & $\mathrm{N}$ & $\mathrm{X}$ & $\mathrm{s.s}$ & $\mathrm{Sd}(\mathrm{df})$ & $\mathrm{t}$ & $\mathrm{p}$ \\
\hline Çevre Dostu & Kadın & 170 & 3.78 & .94 & \multirow{2}{*}{372} & 1.25 & .21 \\
\cline { 2 - 6 } Davranı̧̧ & Erkek & 204 & 3.90 & .78 & & & \\
\hline $\begin{array}{l}\text { Çevreye } \\
\text { yönelik } \\
\text { Tutum }\end{array}$ & Kadın & 159 & 3.96 & .64 & \multirow{2}{*}{351} & 1.47 & .14 \\
\cline { 2 - 6 } & Erkek & 194 & 4.10 & 1.10 & & & \\
\hline
\end{tabular}

Tablo 5'e göre, bağımsız örneklem t-testi analizleri çevre dostu değişkeni açısından incelendiğinde kız ve erkek ögrenciler arasında $(\mathrm{t}(372)=1.256, \mathrm{p}=0.210)$ anlamlı bir farklılık bulunmamaktadır. Çevre dostu davranış puanları incelendiğinde ise erkek öğrencilerin çevre dostu puan ortalaması $(=3.90$, $\mathrm{Ss}=.78)$, kız öğrencilerin çevre dostu davranış puan ortalamalarından $(=3.78, \mathrm{Ss}=.94)$ daha yüksektir fakat bu fark anlamlı değildir.

Bağımsız örneklem t-testi sonuçları çevreye karşı tutum değişkeni açısından incelendiğinde cinsiyet değişkeni açısından anlamlı bir farklılık göstermemektedir $(\mathrm{t}(351)=1.47 \mathrm{p}=.14)$. Çevreye karşı tutum puan ortalamaları incelendiğinde ise erkeklerin tutum puan ortalamaları $(=4.10, \mathrm{Ss}=1.10)$, kızların tutum puanları ortalamaları $(=3.96, \mathrm{Ss}=.64)$ göre daha yüksek çıktığ 1 fakat bu farkın anlamlı olmadığı sonucuna ulaşılmıştır.

\section{Sonuç, Tartışma ve Öneriler}

Bu çalışmada İlköğretim 6.sınıf öğrencilerinin çevre dostu davranışları ve çevreye karşı tutumlarının ne düzeyde olduğu ve çevre dostu davranışlarının ve çevreye karşı tutumların cinsiyete göre farklılık gösterip göstermediği incelenmiştir. Araştırma sonuçları 6. Sınıf öğrencilerinin çevreye dostu davranışları ile çevreye karşı tutum puanlarının pozitif ve yüksek düzeyde olduğunu göstermektedir. $\mathrm{Bu}$ sonucun fen bilimleri müfredatında çevreyi korumaya ve çevre bilincini arttırmaya yönelik kazanımların arttırılmış olması ve öğrencilerin öğrenim gördükleri okulların eko okul gibi çevreye yönelik etkinliklerin yapılarak farkındalıklarının arttırıldığı okullar olmasından kaynaklandığı düşünülmektedir. Akıllı ve Yurtcan (2009), Gök ve Afyon (2015), Kuhlemeier, van den Bergh ve Lagerweij (1999) yaptıkları çalışmalarda bezer sonuçlarla bu çalışmanın sonuçlarını desteklemektedirler. Uzun (2007) ise çalışmasında öğrencilerin çevreye yönelik pozitif düzeyde olumlu düşüncelere sahipken, çevreye yönelik davranışlarının düşük düzeyde olduğu istendik düzeyde olmadığı sonucuna ulaşmıştır.

Çalışmanın diğer bir sonucu ise öğrencilerin kız öğrencilerin ve erkek öğrencilerin çevre dostu davranışları ve çevreye karşı tutumları anlamlı bir farklılık göstermemektedir. Alp, Ertepınar, Tekkaya ve Yılmaz (2008), Demirel (2016), Özay-Köse (2010), Said, Yahaya ve Ahmadun (2007), ve Sarıgöz (2013) cinsiyetin öğrencilerin çevreye yönelik davranışları ile farklılık gösterip göstermediklerini incelemiştir. Alp vd. (2008), ilköğretim öğrencilerinin çevre bilgi ve tutumlarının sosyodemografik değişkenler açısından anlamlı bir farklılık gösterip göstermediğini incelendiği araştırmada; öğrencilerin çevreye karşı tutumlarına ilişkin cinsiyet farkının kızlar lehine istatistiksel olarak anlamlı bulunurken, çevre dostu davranışlarının cinsiyet bakımından kız ve erkek öğrenciler arasında istatistiksel olarak anlamlı bir farklılığın olmadığı belirtilmiştir. Benzer şekilde Akıllı ve Yurtcan (2009), Atasoy ve Ertürk (2008), Değirmenci (2012), Gök ve Afyon (2015), Kaya, Akıllı ve Sezek (2009), Önder (2015), Şama (2003) çalışmalarında kız öğrencilerin çevreye karşı tutumlarının erkek öğrencilere göre daha olumlu

92 I P a g e www.iiste.org 
olduğu sonucuna ulaşmışlardır. Bu çalışmaların yanı sıra literatürdeki çalışmalardan Said, Yahaya ve Ahmadun (2007) ve Özdemir ve Arık (2013), ortaöğretim öğrencilerinin çevre ile ilgili bilgi seviyesi, çevreye yönelik tutum ve anlayış düzeylerini, Özay-Köse (2010) lise öğrencilerinin çevreye karş1 tutumlarına etki eden faktörleri; Demirel (2016) ortaokul öğrencilerinin çevreye yönelik davranışlarını sınıf seviyesi ve cinsiyet faktörüne göre; Sarı̈öz (2013) ortaokul öğrencilerinin çevreye yönelik davranışlarının ve düşüncelerinin cinsiyet değişkenine göre araştırdığı bu çalışmalarda, kız öğrencilerle erkek öğrencilerin çevre dostu davranış ve tutumları arasında anlamlı bir fark bulunamamıştır. Okullarda erkek öğrencilerin çevreyi korumaya yönelik etkinlik sürecine kız öğrencilerle birlikte erkek öğrencilerinde aktif olarak katılımlarının sağlanması, okullarda tüm öğrencilerin ilgisini çekecek etkinliklerin yapılması literatürdeki kızlar lehine olan çevreye yönelik tutum düzeyini ortadan kaldırdığı düşünülmektedir. Ballantyne and Packer (2002), öğrencilerin doğal alanlarda kazanılan çevre eğitimi tecrübelerini, çevreye karşı tutumlarını ve çevreye yönelik davranışlarını incelediği bu araştırmasında; doğal ortamlarda gerçekleştirilen öğrenme süreçlerinin öğrenciler için ilgi çekici olduğunu bununla beraber öğrencilerin çevreye yönelik tutumlarında ve çevreye yönelik davranışlarında anlamlı farklılıklar ortaya çıktığını belirtmiştir. Günümüz de yer alan çevresel sorunların önlenmesi, öncelikli olarak bireylere verilmesi gereken etkili bir çevre eğitimine bağlıdır. Bu bakımdan eğitimciler ve araştırmacılar öğrencilere çevre bilincini geliştirmesini amaçlayan uygulamalı çalışmalara daha fazla önem vermelidirler. Öğrencilerin öğretim sürecinde çevre ve çevre sorunlarına dair bilgi ve farkındalıklarını geliştirmek, tutum ve davranışlarında olumlu etkiler gerçekleştirebilmek, öğrendikleri bilgileri daha kalıcı olmasını sağlamak için verilen çevre dersleri, doğa eğitimleri, eko okul etkinlikleri arttırılmalıdır ve öğretim sürecinde öğrenci merkezli, aktif katılım sağlayan farklı ögretim yöntem ve teknikleri uygulanabilir.

\section{Kaynakça}

Akıllı, M. \& Yurtcan, M. T. (2009). İlköğretim fen bilgisi öğretmeni adaylarının çevreye karşı tutumlarının farklı değişkenler açısından incelenmesi (Kazım Karabekir Eğitim Fakültesi Örneği). Erzincan Ĕ̆itim Fakültesi Dergisi, 11, 119-131.

Alp, E., Ertepınar, H., Tekkaya, C. \& Y1lmaz, A. (2008). A survey on turkish elementary school students' environmental friendly behaviours and associated variables. Environmental Education Research,14(2),129-143.

Atasoy, E. \& Ertürk, H. (2008). İlköğretim öğrencilerinin çevresel tutum ve çevre bilgisi üzerine bir alan araştırması. Erzincan Eğitim Fakültesi Dergisi, 10(1), 105-122.

Ayvaz, Z. (1998). Çevre ĕgitimine giriş, İzmir: Çevre Eğitimi Merkezi Yayınları.

Ballantyne, R. R. And Packer, J. (2002). Nature- based excursions: school students' perspections of learning in natural environments. International Research in Geographical and Enyironmental Education, 11(3), 218-231.

Demirel, R. (2016). Ortaokul öğrencilerinin çevreye yönelik davranışlarının belirlenmesi eğitiminde kuram ve uygulama. Journal of Theory and Practice in Education, 12(4), 863-878.

Değirmenci, M. (2012). İlköğretim öğrencilerinin çevreye karşı tutumlarının farklı değişkenler açısından incelenmesi (Kayseri ili örneği). Journal of European Education, 2(2), 47-53.

Erol, G. H., ve Gezer, K. (2006). Sınıf öğretmenliği öğretmen adaylarının çevreye ve çevre sorunlarına yönelik tutumları. International Journal of Environmental and Science Education, $1(1), 65-77$.

Erten, S. (2005). Okul öncesi öğretmen adaylarında çevre dostu davranışların araştırılması. Hacettepe Üniversitesi Ĕ̈itim Fakültesi Dergisi, 28, 91-100.

Fraenkel, J. R. \& Wallen, N. E. (2006). How to Design and Evaluate Research in Education (6th edition). USA: Mc Graw Hill, Inc.

93 | P a g e

www.iiste.org 
Gök, E \&Afyon, A. (2015). İlköğretim öğrencilerinin çevre bilgisi ve çevresel tutumları üzerine alan araştırması. Journal of Turkish Science Education, 12(4), 77-93.

Hamamcı, C. (1997). "Çevrenin Uluslararası Boyutu" Insan Çevre Toplum, Der: R. Keleş, Ankara: İmge Yayınları, 394-412.

Hamarat, B., Güler, O., Duran, E., Gümüş, M., ve Tufan, E. (2014). Çevresel tehdit, çevresel bilinç ve çevresel tutum çevre odaklı davranışı etkiler mi? Çanakkale sivil toplum kuruluşu örneği. Uşak Üniversitesi Sosyal Bilimler Dergisi, 7(2), 26-56.

Higde, E., Oztekin, C. \& Sahin, E. (2017). Turkish pre-service science teachers' awareness, beliefs, values, and behaviours pertinent to climate change. International Research in Geographical and Environmental Education, 1-11.

Kabaş, A. (2018). Minik Eller İle Yerli Domatesler. TÜBİTAK 4004 Doğa Eğitimi ve Bilim Okulları Projesi, Proje No. 118B291.

Kahyaoğlu, M., Daban, Ş ve Yangın, S. (2008). İlköğretim öğretmen adaylarının çevreye yönelik tutumları. Dicle Üniversitesi Ziya Gökalp Eğitim Fakültesi Dergisi, 11, 42-52.

Kaya, E., Akı1lı, M. \& Sezek, F. (2009). "Lise öğrencilerinin çevreye karşı tutumlarının cinsiyet açısından incelenmesi”. Mehmet Akif Ersoy Üniversitesi Eğitim Fakültesi Dergisi, (18), 43-54.

Kavak, Y. (1997). Dünya'da ve Türkiye'de İlköğretim. Ankara: Pegem Yayınları.

Kuhlemeier, H., van den Bergh, H. \& Lagerweij, N.(1999). Environmental knowledge, attitudes and behavior in dutch secondary education. Journal of Environmental Education, 30 (2), 4-14.

Mertig, A. G. (2003). Michigan State University environmental survey of freshman - Fall 2000 and Spring 2003, Unpublished raw data, Michigan State University, East Lansing, MI.

Önder, R. (2015). İlköğretim öğrencilerinin çevre tutumlarının incelenmesi. Karabük Üniversitesi Sosyal Bilimler Enstitüsü Dergisi, 5(1), 115-124.

Özay-Köse, E. (2010). Lise öğrencilerinin çevreye yönelik tutumlarına etki eden faktörler. Türk Fen Eğitimi Dergisi, 7(3), 198-211.

Özdemir Benli, E. \& Arık, S.(2013). Ortaokul öğrencilerinin benlik sayg1 düzeylerinin ve sürdürülebilir çevreye yönelik tutumlarının incelenmesi. Tarih Okulu Dergisi, 6, 641-655.

Said, M.A., Yahaya, N. \&Ahmadun, F. (2007). Environmental comprehension and participation of malaysian secondary school students. Environmental Education Research, 13(1), 17-31.

Sarıgöz, O. (2013). Ortaöğretim öğrencilerinin çevre ile ilgili davranış ve düşüncelerinin değerlendirilmesi. Yüzüncü Yll Üniversitesi Eğitim Fakültesi Dergisi, 5(1), 87-105.

Şahin, N. F., Cerrah, L., Saka, A., ve Şahin, B. (2004). Yüksek öğretimde öğrenci merkezli çevre eğitimi dersine yönelik bir uygulama. Gazi Eğitim Fakültesi Dergisi, 24(3), 113-128.

Şama, E. (2003). Öğretmen adaylarının çevre sorunlarına yönelik tutumları. G.Ü. Gazi Eğitim Fakültesi Dergisi, 23, 99-110.

Thompson, S. C. G., \& Barton, M. A. (1994). Ecocentric and anthropocentric attitudes toward the environment. Journal of Environmental Psychology, 14, 149-157. 
Türküm, A., S. (1998). Çağdaş Toplumda Çevre Sorunları ve Çevre Bilinci. Anadolu Üniversitesi. G.Can (Ed.). Çağdaş Yaşam Çağdaş İnsan. Anadolu Üniversitesi Açık Öğretim Fakültesi İlköğretim Öğretmenliği Lisans Tamamlama Programı, Eskişehir, 165-181.

Uzun, N. (2007). Ortaöğretim Öğrencilerinin Çevreye Yönelik Bilgi ve Tutumları Üzerine Bir Çalışma. Yayınlanmamış Doktora Tezi. Hacettepe Üniversitesi, Fen Bilimleri Enstitüsü, Ankara.

Uzun, N. \& Sağlam, N. (2006). Ortaöğretim öğrencileri için çevresel tutum ölçeği geliştirme ve geçerliliği. Hacettepe Üniversitesi Eğitim Fakültesi Dergisi, 30, 240-250.

Uzunoğlu, S. (1996). Çevre Eğitiminin Amaçları, Uğraş Alanları ve Sorunları. Ekoloji Çevre Dergisi, 21,7-12. 